\title{
Learning Devices Development on Descriptive Writing for Foreign Language Based on Berlo's SMCR Communication Model of Secondary School Student
}

\author{
Syukur Saud \\ State University of Makassar, Indonesia \\ A. Jufri \\ State University of Makassar, Indonesia \\ Muhammad Asfah Rahman \\ State University of Makassar, Indonesia \\ Salam \\ State University of Makassar, Indonesia
}

\begin{abstract}
This research and development study aims to develop a product in the form of German descriptive writing learning device based on SMRC Berlo communication for Senior High school. The study procedure follows the first the phases of Thiagrajan 4-D Development Stage: (1) defining Stage; (2) designing Stage; (3) developing stage; (4) disseminating stage. This research involved senior secondary school teachers and students during the defining and developing phases. Besides, experts were involved during the validation of the product. The newly developed learning devices consist of 1) lesson plan, 2) teaching materials/student's book, 3) teacher's handbook, 4) students' worksheet, and 5) learning result test. Quality of the learning device is considered from three aspects namely: validity, practicability, and effectiveness. Validity of the learning device is based on the result of the try-outs including the students' German descriptive texts.
\end{abstract}

Index Terms - German language, descriptive writing, learning device, Berlo's SMCR communication model

\section{INTRODUCTION}

The need for authentic and meaningful learning materials for everyday students' life and the optimal use of multimedia is a must. In fact, this is supported by the orientation of education in Indonesia that has begun to shift to life skills orientation. The content-based curriculum that was previously to competency-based, school-level curriculum has finally been changed to 2013 character-based curriculum. Consequently, the school is required to improve its quality standards of good management and its human resources in order to create civilized people with all desired good characters synergizing with the community.

Competent teachers can produce quality of education through varied classroom instructional processes. Lack of understanding of the conditions and potentials of the students and the reluctance to continue renewing their competencies might become some of the factors restricting the success of teaching. The learning process should provide an opportunity for the students to fully explore, and engage in logical, holistic, objective and creative thinking. A consequence of the low quality of the teachers is likelihood of not achieving the best possible condition for each student to learn or to achieve the desired learning objective.

Foreign language learning context, especially Germany in Indonesia is not conducive. Exposure the German language outside of school classroom is very rare. The presence of native speakers whom the students may use the language is very scary. Besides, German can hardly see around the student's environment. Such contexts certainly limit the use of the language that the students have learned at schools in the real life outside the classroom. Hadley (1993) states that the study and practice in the context that the meaning is more effective than isolated learning through memory and repetition (p. 290).

Among the four language skills of listening, speaking, reading and writing, is a skill that considered the most difficult for most students, including writing in their mother tongue Indonesian. Students often have difficulty in positing their ideas into the target language because they are not accustomed to expressing ideas based on their sensual experiences (sight, hearing, smell, taste, and touching) in writing. Presumably, they will be able to overcome their difficulties in 
writing when they learn to write through a process that involves all their senses. This may also increase their interest and motivation to develop their writing skills.

As described above, therefore, writing skill became the focus of research in order to get an overview of descriptive writing learning process holistically. The author conducted the research by using development or Research and Development (R \&D).

Power and Hubbard (1992) define writing as a communication media of someone to himself and other people in a different time and place. It means that, if someone writes then he tries to express his intention or message in a written form in a different time and place with his writing (p. 68-69). It is language skill used to communicate indirectly. It is not faced to face with other people.

Writing is a productive and expressive activity. In this writing activity, a writer must be competent in utilizing graphology, language structure, and vocabulary. This writing skill will not be mastered automatically, but it requires test, and lot of routine practices (Tarigan, 2008, p. 19)

Hamsa (2008) defines learning to write as a system has some components. As a system, the position of the components are interrelated and mutually supporting each other. Each of the component's interact and work together in order to achieve the goal of learning to write, which has the competence to pour the ideas, thoughts, and information written by using proper and correct grammar (p. 29). Further, Brown (2001) defines it as the acquisition of knowledge or skills through learning, experience, and instruction. Learning is a change in tendency in permanent Act that is the result of reinforcement (p. 337).

Hadley (1993 defines some purposes of learning to write in the classroom, including 1) to support other language skills especially for assigning grammatical and vocabulary mastery, 2) to assist the students in writing for a variety of purposes such as communicating ideas, feelings and attitudes, 3) to guide the students to understand and develop writing skills as a rhetorical strategy with specific discourse and 4) to empower cognitive capabilities of the students enable them to solve problems (p. 293-294).

Writing as a process comprising stages, namely: planning, writing drafts, responding, revising, editing, evaluating, and publishing the final stages of writing. The stages according to Richards (2003) may be random and not necessarily sequential (p. 315).

Sometimes stages of drafting can be affected by the planning and revision stages can be the formulation stage of writing, or vice versa. This means that the writing process is a series of work related and affected each other. Writing begins with the planning stage. This stage is carried out through various activities that strive to arouse the interest of students to write. The second stage is drafting. Students begin to focus on the smooth writing without seeing their grammatical errors. The next stage is to respond to students' writing. The next stage is revision and editing, followed by assessment and publication.

The Teaching/learning material is one of the factors that determine the success of the learning process of students. According to Richads and Renandya (2003), an effective learning material should meet the needs of the students and the teachers. Learning materials can be adapted according to the contexts and needs of the students. They add that good teaching materials reflect a variety of things, for example, language learning materials should be functional and contextual. (p. 84-88)

The teaching/ learning material may be in the form of printed material such as books and paper work, non-printed materials such as tapes, videos, computer-based material, and the combined material between the printed and nonprinted materials including materials on the internet. For the students, the teaching material is the main source of representation contact between the students and the teachers. Therefore, the role and use of learning materials in the language learning program, especially in learning to write, is a significant aspect that should get special emphasis.

There are two important aspects that should be taken into account in learning to write or writing instruction, i.e. communication aspects and aspects of language precision. These are the aspects that are often considered in measuring the students' writing as suggested by Bolton (1995). The communication aspect includes contents such as principal thoughts to be communicated and the forms including writing systematicity, cohesion and coherence. The aspects of language precision consist of (1) selected words: the proper word choice, correct usage of word meaning, and phrases, (2) morphology: correct word formation, (3) syntax: use correct use of patterns of phrases and sentences, and (4) orthography: the writing of words, punctuation, uppercase and lowercase letters, and correct spelling (Bolton, 1995, p. 132-136).

In a writing class, learning/teaching materials are very important. In order for the students to be motivated and interested in learning to write, the Berlo's communication model may apply to develop the writing learning devices. The models involve all sense as the channel for the messages to be conveyed. The SMCR model of communication proposed by David K Berlocan is seen in the following figure: 


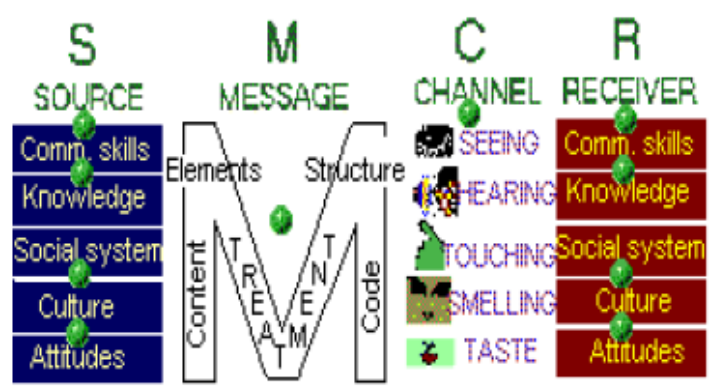

Figure 1. Berlo's SMCR Model of Communication

Description of an item or object may be better communicated when using al, the senses. Most aspects of the subjects can be described, i.e. how to looks like (seeing), how it sounds (hearing), how it feels (touching), how it tastes (tasting), and how it smells (smelling). It is assumed that writing materials which require the students' senses when practicing writing may lead the students to write quality descriptive texts. Hence, learning takes place and communication will be effective.

The present study is an R \& D research which focuses on the development of instructional kits for improving the German descriptive writing skills of the students. The instructional kits to be developed consist of teaching materials, students' work activity/activity sheets, teacher's guide, and lesson plans which are based on Berlo's SMCR communication model.

\section{METHODOLOGY}

This R \& D research proceed following the steps in Thiagarajan, Semmel and Semmel, known as 4-D (defines, design, develop, and disseminate) as follows:

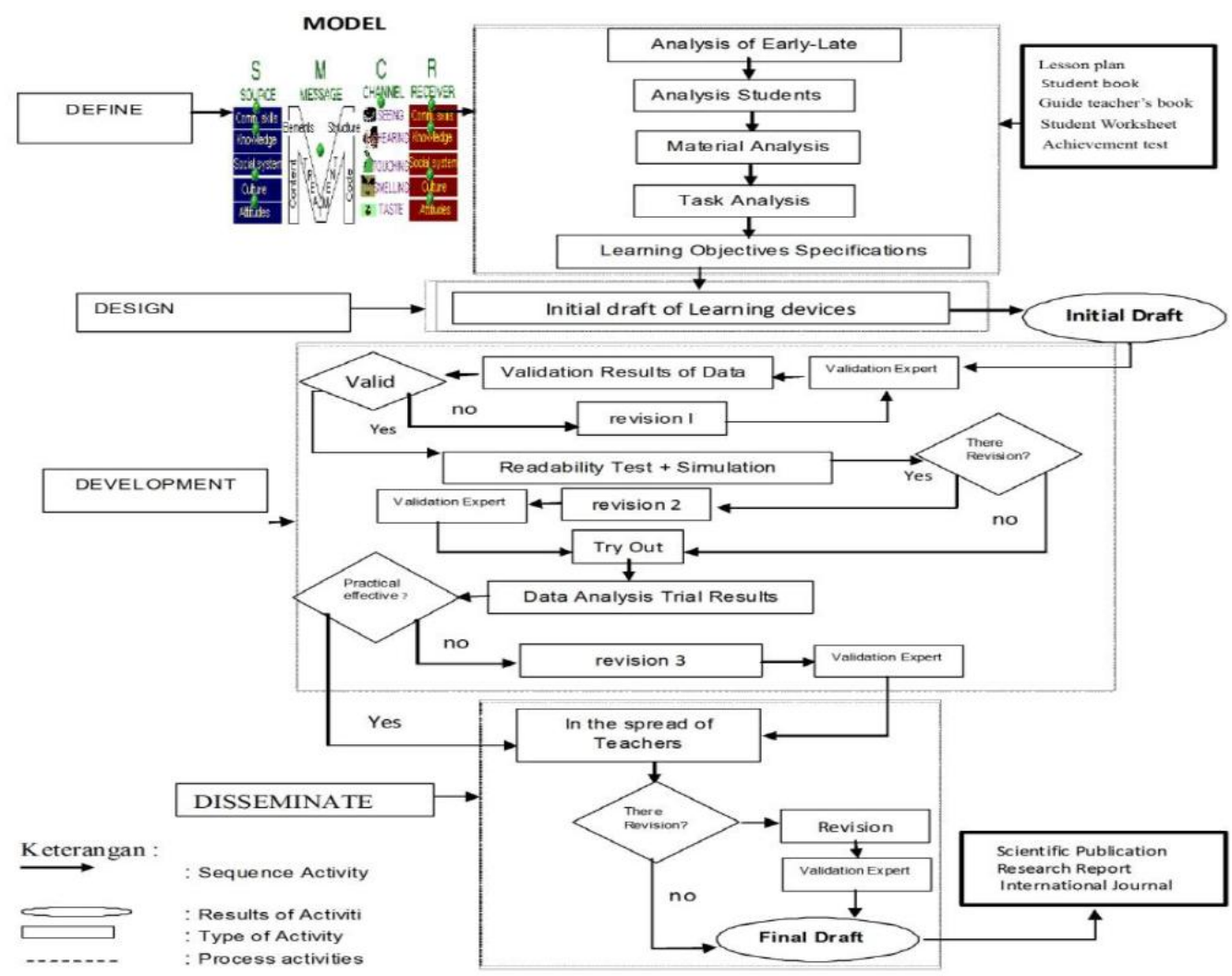

Figure 2. Modifications of Learning Tool 4-D Thiagarajan

\section{RESULTS AND DISCUSSION}

\section{A. Result}

The results of the study are presented following the stages of the 4D development model: defining, designing, developing, and disseminating. 


\section{Defining Phase}

During this phase, an analysis was carried out based on information obtained from the senior secondary school teachers and students. Besides, the available learning materials, learning objectives, and learning tasks currently in use were also reviewed. Following in the results of the analysis and reviews:

\section{Information of senior secondary school teachers}

Based on the discussions with the German language teachers at public senior secondary school (SMAN 4), Bantimurung Maros, it is found that the teachers of German in their language-learning activities in the school use conventional learning strategies. The teachers not understand well the methods of teaching and learning that may be effective, and this may have resulted in an interaction in the learning process particularly in the development of German writing skills which are not running optimally. Their student does not yet have the ability to write basic German language well; this poor condition will positively hamper the achievement of learning outcomes of students' writing skills, especially in writing a descriptive of German texts.

\section{Information of the Students}

The students participated in this study were Class XII students of SMAN 4 Bantimurung Maros academic year 2012/2013 consisting of 24 students randomly selected from the six classes that took the subject of German. In the analysis, the researcher found out the background knowledge; the language used, and the level of cognitive development of students.

\section{Material Currently in use by the teachers and students}

The purpose of this review was to identify, specify, and develop materials that the students learned, and then the materials were arranged and organized appropriately. For example, the material was about Hobby und Freizeit as identified in the content standards. The outline of the material in this study is presented in the following figure:

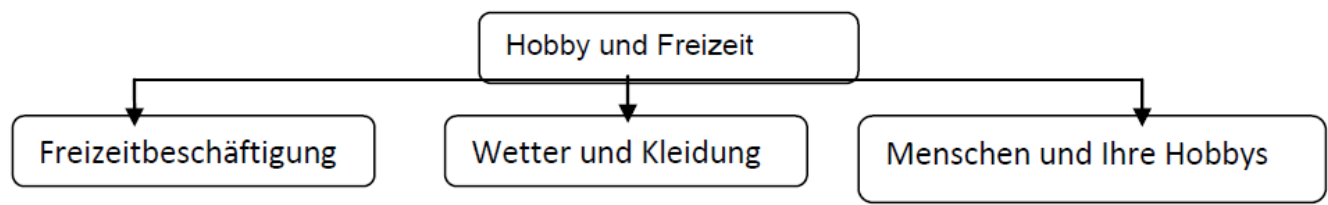

Figure 3. Material elaboration of Hobby and Freizeit

\section{Task Analysis}

The results of the learning task analysis for the topic Freizeit / Hobby in this study are as follows: 1) Write words, phrases, sentences, and simple dialogue about the sub-theme Freizeitbeschäftigung, 2) Connect parts of a sentence and write the words that match the text in the reading passage, 3) Determine appropriate vocabulary in context in the subtheme Freizeitbeschäftigung, 4) Writing words, phrases/sentences and simple dialogue about the sub-theme Kleidung Wetter und Kleidung in der Freizeit, 5) Determine the use of of conjunction's weil Präsens in sentences appropriately, 6) Practice simple phrases in context, 7) Arrange sentences into discourse, 8) Read the text and then write a descriptive essay based on context, and 9) Specify the command line usage, regular and irregular verbs, accusative object, negation and verb capital "Mogen" with appropriate context.

\section{Review of learning objectives}

This review was intended to formulate or reformulate all learning objectives related to the selected topics. The existing goal and basic competencies became the basis for writing indicators of the learning objectives achievement. All the indicators were used as reference for the preparation of the materials on Freizeit/hobbies and the designing of all learning tools for this study.

\section{Designing Phase}

This stage aims at designing a prototype of the learning devices. The results of the designing phase consist of five learning tools, namely Lesson Plan (RPP), Student's Book, Teacher's Guide Book, Student Worksheet, Test Results and Learning. Learning devices in the design phase (design) is called the initial draft. The results of each activity in the design phase are described as follows:

\section{Test Preparation}

Preparation of the test is based on the analysis of the material and analysis tasks outlined in the indicators of achievement. The test in question is the achievement test on the material avocation / hobby. Achievement test was developed in the form of essays.

\section{Media selection}

The media selection is conducted to determine the proper media in the presentation of the subject matter to write based communication model Berlo SMCR. Media selection process adapted to the analysis of materials, task analysis, and characteristics of students as well as the standards of competence and basic competences. From the results of this media selection, determined that the instructional media needed include: (a) the board, (b) markers, (c) eraser, (d) LCD, (e) Video, (f) Laptop, and (g) Speaker.

\section{Format selection}


The format selection as a learning device aims to select or design a format for designing learning devices, the selection of strategies, approaches, methods of teaching and learning resources. The contents of the learning device prepared in accordance with the principles, characteristics and measure's communication models Berlo SMCR. In general, the format of learning is described as follows:

a. Lehrvorbereitung (Lesson Plan)

Lesson Plan is designed based on the communication model Berlo SMCR procedures and organizational measures of learning separately to achieve the stated goals. The steps are performed in the preparation of lesson plans namely: (1) determine the allocation of time, (2) determine SK, KD, and indicators of achievement, (3) formulate learning objectives based SK, KD, and indicators that have been defined, (4) identify teaching materials based on the subject matter, (5) determine the learning method to be used, (6) formulate learning steps consisting of initial activities, core activities, and the final activity, (7) determine the source and medium of learning required. Based on this lesson plan developed includes the following components: a standard of competence, basic competence, indicators of achievement, learning objectives, learning materials Berlo SMCR model of communication. Based on the material scope craze / hobbies, the RPP is made for three (3) meetings that have allocated time each 2 x 45 minutes.

b. Kursbuch (Learning Material).

Learning materials developed in learning the German language writing is based on communication model Berlo SMCR for freizeit/hobby materials. It is presented by using the channel: seeing, hearing, touching, smelling, tasting. Characteristics that distinguish teaching materials designed based communication model Berlo's SMCR with other teaching materials is the existence of directives that facilitate students in constructing their own knowledge based on the five senses at every stage of the material presented. Components consist of teaching materials: basic competencies, indicators, independent exercises, auditory media and literature that are the end of the teaching materials.

c. Lehrhandbuch(Teachers' Handbook)

Teacher manual developed for writing skills-based model of communication SMCR Berlo contains Number of each section and chapter in the books students, implementing the material in the classroom with senses: seeing, hearing, touching, smelling, tasting, alternatively answer the questions contained in the books students.

d. Arbeitsbuch (Student Worksheet)

At this stage the Arbeitsbuch developed as much as 3 pieces of communication model and designed in the converted from Berlo SMCR model of communication material on Berlo SMCR. Arbeitsbuch also contains instructions that accompanied the empty space as a place for students to write down their answers as the solution of any contextual problem. Arbeitsbuch component includes: instructions, contextual issues that come with channel: seeing, hearing, touching, smelling, tasting as a symbol in the model of communication SMCR Berlo and empty spaces as a place best student. Through the use of Arbeitsbuch, expected to be helpful in understanding the lessons and improve the skills of students in writing a language in Germany significantly.

e. Test des Lernergebnis (Learning outcomes)

Teacher manual developed for writing skills-based model of communication SMCR Berlo contains: Number of each section and chapter f). Test des Lernegebnis (the Test Results).

The writing skills test is organized based on the theory of adaptation evaluation writing skills as well as paying attention to the teaching goals Bolton to write language-based communication model Germany SMCR Berlo which includes thoughts or opinions in writing in the language of Germany is communicative. According to Bolton indicators assessed in writing ability are as follows: (1) the communicative aspects: (a) content (theme which is communicated entirely), (b) the form (Systematic of writing, cohesion and coherence), (2) aspects of the precision of the language: (a) diction (selection of the right word), (b) morphology formation of words correctly, (c) syntax (the use of patterns of phrasing and sentences correctly, upper and lower, and the correct spelling).

\section{Development Phase}

The purpose of this stage is to produce a draft revised learning devices based on the input of experts and data obtained from test results and readability data. Activities performed at this stage are the assessment of experts, readability tests, simulations and tests in class XII high school. The respective activities at this stage are described as follows:

\section{Expert Assessment}

After all the initial drafts studies are completed at the stage of design, an assessment is validated by some experts. The experts in question in this case are the competent validator to conduct an assessment of the learning tool. Advice from the validator is used as an object to make a revision for the development phase. Generally the validation experts consist of:

a. the content of the study, whether the content of the material as well as in accordance with the learning objectives to be measured (the validation material),

b. Language: (1) whether the sentence on the device using suitable language learning the rules of German language? (2) Whether the sentences on learning devices do not cause the double interpretation?

\section{The readability Test and lesson plan simulation.}

The developed initial draft of the devices, the observation sheet and student response made test for readability and lesson plan simulation. The purpose of this activity is to obtain input device of all learning and student response that can 
now be read and clearly understood and can be implemented in the field. This activity is carried out on some of the following activities:

a. Researchers determine one groups of study consisting of 24 students. They were taken four students from six German language learning classroom grade XII SMA Negeri 4 Bantimurung Maros regency randomly. Selection of subjects is done with attention to the heterogeneity of students.

b. All students are required to read the entire contents of the book: students, Students' worksheet, Test Results and Student Response for Questionnaire Sheet. After that they were asked to deliver when there are words or sentences that they cannot understand.

c. The two candidates of observer were asked to read the observation sheet about ability of the teachers to manage learning, the student activities, observation sheets and observation device implementation (as much as one person). After that, they were asked to convey things that they could not understand the meaning. While other observer candidates are asked to read: teachers guide, learning implementation plan, and Test Results Sheet, and Student Worksheet, and then they are asked to convey things that are not clear or expected.

d. Researchers conduct a simulated toward one or two lessons plans in class XII, while the two candidates for the observer has been appointed to act as an observer.

e. Researchers conduct the revision of learning devices; observation sheet and questionnaire form for student response based on input from previous activities.

\section{Testing of Learning Device}

Testing of learning device in the field aims to obtain data or input from teachers, students and observers toward all of the learning that have been compiled as a basis for revision of the learning tool.

\section{Dissemination Phase}

The resulting device on the development phase will be further disseminated or socialized to a limited extent in Germany language teacher SMA Negeri 4 Bantimurung Maros regency. Dissemination of the results is obtained some suggestions, and they are used for revising the initial draft to the final draft. The suggestions from the participants are as follows:

1. Berlo SMCR model of communication Development is presented in the Kursbuch and Arbeitsbuch is preferably tailored to students' cognitive.

2. Learning Tool developed in the Berlo SMCR model of communication approach should not only be used on one Germany-Language skill.

\section{B. Discussion}

The achievement of research objectives that were elaborated is how far the planned research objectives are achieved. This achievement is associated with the availability of early learning device based on Berlo's SMCR Model of communication, in which in the second and third year will be developed to examine its validity, effectiveness, and practicability.

The intended specific findings in this chapter are findings which were discovered during early arrangement of learning device of writing based on Berlo's SMCR model of communication, particularly for the condition of students who become the subject of this research.

A visit to the location of the research had been conducted several times for a variety of purposes such as observing the research location, socializing of teaching model to the Headmaster and the teachers, holding discussions with the teachers, especially to those who teach German language.

Based on these observations, information obtained was that students have taught language subject since they are in the X, XI to XII grade. It is conducted because German language subject is an important subject to learn. Characteristics that distinguish between German writing learning device based on Berlo's SMCR model of communication and German language learning device that has existed before are portrayed as follow:

\section{a. Syllabus and lesson Plan}

Syllabus and lesson plan designing for German language writing skills are based on the learning phases. They aim to describe a procedure in organizing learning to achieve one basic competence which is established in the competence standard. The committed steps follow learning phases that are based on Berlo's SMCR communication. If it is compared with syllabus and lesson plan that exist before, syllabus and lesson plan based on communication model are still lack used in schools especially in the school in which this research conducted. Characteristics that distinguish between the syllabus and lesson plan for Berlo's SMCR model of communication and the existing syllabus and lesson plan are as follow:

1) In Berlo's SMCR model of communication, the syllabus and lesson plan is actively expected to construct students' own knowledge, and the teacher is just to facilitate, guide, and motivate them in constructing their knowledge. Whereas, the existing syllabus and lesson plan are presented by conventional way,

2) In Berlo's SMCR model of communication, Syllabus and lesson plan focus on the students learning completeness. Whereas existing syllabus and lesson plan concern to the material completeness of each meeting.

\section{b. Kursbuch (teaching material)}

This kursbuch can be used whether in the learning process of the class or autodidact. Kursbuch that has been designed for German language writing skill is in the form of a combination between materials innovatively and giving 
symbols of channel: seeing, hearing, touching, smelling, and tasting. Moreover, this kursbuch is also completed with pictures and illustration that can guide students to understand the concept that presented inside it which differentiate it from other kursbuch.

\section{c. Arbeitsbuch (Students' worksheet)}

Arbeitsbuch is a guide for students used to find a concept or procedure by constructing their own knowledge. This Arbeitsbuch characteristic contains a group of questions which guide students in writing based Berlo's SMCR communication model with the instructions of symbols from the channel: seeing, hearing, touching, smelling, and tasting and completed with a blank sheet for students to write down their answers.

The constructed Arbeitsbuch on the German writing skills based on Berlo's SMCR model of communication concern Arbeitsbuch arrangement purposes. The purposes are: (1) integrating all of the channel: seeing, hearing, touching, smelling, and tasting as a place and symbols which then guide students in utilizing all of their sense aspects in working every question that are presented inside it. (2) Stimulating students to utilize all the aspect of sense based on their experience and express it German language compose, so the students are more motivated to learn and believe more to the answer that they get.

\section{d. Lehrhandbuch (guidebook)}

Lehrhandbuch that is designed for German language skills writing material based-Berlo's SMCR communication model is a guidebook for teachers in the teaching and learning process that contains about the implementation of Berlo's SMCR communication model, learning concept and alternative answer of every problem. It differentiates Lehrhandbuch that becomes the earlier design from teachers' handbook that has existed.

\section{CONCLUSION AND SUGGESTION}

\section{A. Conclusion}

Based on the results achieved as has been described above, the researchers take some conclusions as follows:

1. Teachers need to pay attention to communication elements in writing especially for teaching of German language.

2. Learning devices development on descriptive writing based on Berlo's SMCR communication model need to be implemented.

3. Learning devices consist of lesson plan, students' textbook, teachers' handbook, students' worksheets and the learning test outcomes.

\section{B. Suggestion}

The results of this research provide implications to various parties, so it is recommended to:

\section{The development of Science}

The results of this research show that the model of communication skill enhancement in Berlo's SMCR model in the writing German for descriptive texts language in Senior High School, either from conceptual or practice side possesses feasibility to be implemented in the process of German language learning.

\section{Problem Solving of Education}

Process of German language learning still tends to use grammatical method that is oriented to the left-brain development and lack to the right-brain function development. Through the implementation of Berlo's SMCR model in which communication elements are functioned optimally so it can improve German descriptive writing capability because components in this SMCR model are able to equalize the way of the both brain work. Therefore, teachers of German language subject to be able to apply this Berlo's SMCR model to the writing descriptive text.

\section{Institutional development}

This research result is highly recommended being considered or become an inspiration in improving German language writing skills particularly for the Department of Foreign Language Education/Germany. Thus, it is expected to pay the attention to the elements and components of communication in the process of teaching and learning.

\section{REFERENCES}

[1] Ahmd, Akbar S. (1992) postmodernism an Islam: Predicamen and Promise, London: Routledge.

[2] Badudu-Zain. (1996). Kamus Umum Bahasa Indonesia. Jakarta: Pustaka Sinar Harapan.

[3] Bolton, Sibylle. (1995). Probleme der Leistungsmessung, Lernfortschrittstests in der Grundstufe, Munchen: Langenscheidt.

[4] Brown, H. Douglas. (2000). Principles in Language Learning and Teaching-4 $4^{\text {th }}$ Ed. New York: Longman.

[5] Brown, H. Douglas. (2001). 'Teaching By Principles: An Interactive Approach to Language Pedagogy:2 ${ }^{\text {nd }}$ Ed. New York: Longman.

[6] Brown, H. Douglas. (2004). Language Assessment: Principles and Classroom Practices. San Fransisco. Longman.

[7] Creswell, John W. (1998). Qualitative Inquiry and Research Design: Choosing among Five Traditions. USA: Sage Publications.

[8] Dale, Edgar. (1969). Audiovisual Methods in Teaching $3{ }^{\text {rd }}$ Edition. Columbus, Ohio. The Dryden Press, Holt, Rinehart and Winston, Inc.

[9] Glaboniat. Mueller. Rusch. Schimitz. Wertenschlag. (2005). Profile Deutsch Lernzielbestimmungen, Kannbescreibungen, Kommunicative Mittel, Niveau A1-A2-B1-B2.C1-C2 Gemeinsam ereuropaeischer Referenzrahmen. Berlin und Muenchen, Langenscheidt KG.

[10] Hadley, Alice Omaggio. (1993). Teaching Language in Context-2 $2^{\text {nd }}$ ed. USA: Heinle \&Heinle Publishers. 
[11] Hamsa, Akmal. (2008). Efektivitas Pembelajaran Menulis Ekspositori Berbasis Media Audio, Gambar, dan Lingkungan pada Siswa Kelas II SMP Negeri 21 Makassar. Program Pascasarjana Universitas Negeri Malang, Disertasi.

[12] http://gauss.unh.edu/ mss/gss/description.html (accessed 15/3/2014).

[13] Krashen, Stephen D. (1981). Second Language Acquisition and Second Language Learning. Oxford: Pergoman.

[14] Krusse, Jarrid. (2009). Iowa Science Teacher Journal. http://ists.pls.uni.edu/ISTJ. (accessed 15/3/2014).

[15] Kumaradicelu, B. (2008). Understanding Language Teaching: from Method to Postmethod. New Jersey: Lawrence Erlbaum.

[16] Linn, Robert L. dan Norman E. Grondlund. (1995). Measurement and Assessment in Teaching, New Jersey; Englewood Cliffs.

[17] Mulyana. (2000). Ilmu Komunikasi Suatu Pengantar. Bandung: PT Remaja Rosda Karya.

[18] Mulyasa, E. (2007). Standar Kompetensi dan Sertifikasi Guru. Bandung: Remaja Rosdakarya.

[19] Power, Brenda Miler \& Hubbard, Ruth. (1991). Literacy and Process: The Heinemann, Reader. USA: Heinemann educational books, Inc.

[20] Tarigan, H.G. (2008). Menulis Sebagai Suatu Keterampilan Berbahasa. Bandung, Angkasa.

[21] Richards Jack C. and Theodore S. Rodgers. (2001). Approaches and Methods in Language Teaching: Second Edition. Melbourne, Cambridge University Press.

[22] Richard, Jack C. \& Renandya, Willy A. (2003). Methodology in Language Teaching: An Anthology of Current Practice-2 ${ }^{\text {nd }}$ Ed. Cambridge University Press, USA.

[23] Tarigan, H.G. (2008). Menulis sebagai Suatu Keterampilan Berbahasa. Bandung, Angkasa.

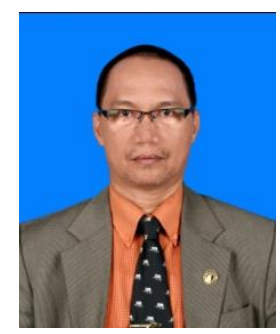

Syukur Saud, was born in Tallang Rilau on September $30^{\text {th }} 1962$. He graduated from elementary school in 1974 and Educational Islamic Teacher for 4 years in Maroangin-Enrekang in 1979, and Educational Islamic teacher part-B for 2 years (1981) in Parepare, and then continuing his study in German language department of the Faculty of Letter and Arts of Institute of Teachers Training and Education (IKIP) of Ujung Pandang. Before finishing his study in 1987, he firstly attended IDS (Integriertes Deutschland Semester) in German Muenchen University (1985). In May-June 1992 he followed Spachkursprogram in Bremen Goethe Institut. In 1995 he took a study at Language Education Department of Post Graduated Program of IKIP Jakarta. And in 1997 he back to Muenchen Goethe Institute to attend Sprachkurs for 3 months.

In the beginning of March 1988 he was accepted as a Lecturer at the Faculty of Letter and Arts of Institute of Teachers Training and Education (IKIP) of Ujung Pandang until now. In 2002-2006 he was pointed as the Secretary of Foreign Language (German) department. Subsequently in 2006-2008 he was believed as the Head of German Language Department. And since 2008 until now he serves as Vice Dean III of Language and Literature Faculty of state University of Makassar. So far, he has published journals entitled Socialization in Student Teaching Landeskunde SMA Negeri 1 Takalar (Makassar, LPM Universitas Negeri makassar, 2010) and Berlo's SMCR Communication Model Development in the teaching of Wortschatz at the Senior High Schools of Makassar (Makassar, Badan Pengembangan FBS UNM, 2010), and also conducted a research report entitled the Implementation of Inter-Cultural Approach (Cross-culture) in the development of Students Speaking Skills of SMA Negeri 1 Sungguminasa.

Drs. Saud, M.pd is one of the members of Indonesian Foreign Langauge (German) Association and Indonesian Muslim Scholars Association. He was the best researchers of State University of Makassar in 2000 and the exemplary lecturer of state university of Makassar in 2000. He was awarded a reward for his 10 and 20 years dedication in education by President of Indonesia in 2007 and 2011.

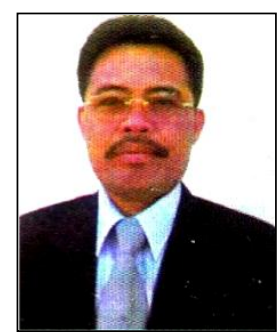

A. Jufri was born in Soppeng, South Sulawesi on December $31^{\text {st }} 1959$. He obtained his bachelor's degree in Foreign Language (German) Education in 1984. He then found his Magister Degree of Education (M.Pd) from Post Graduated Program of State University of Malang in 1986 (graduated for 1 year and 11 mounth) in the Study Program of Indonesian Language Education with the Thesis title: Reading Practice Analysis of Book KD. His Doctoral degree was also obtained from Post Graduated Program of State University of Malang in 2006 (graduated for 2 years and 11 months), by providing title of De: Discourse Structure of Lontara La Galigo. He has taught in the Foreign Language (German) Department of Language and Literature Education Faculty of IKIP of Makassar (State University of Makassar). He obtained his degree of Professor in the field of Language Research Methodology, Language Learning Strategy, and Discourse Analysis in the Post Graduated Program of State University of Makassar.

He had ever attended Foreign Language (German) Education (Sprachkurz) in Iserlohn German in 1987 and become Human Right Instructor of National Police of Indonesia in South Sulawesi for 2001/2002. He has published a number of books entitled Strategy Principle of Language Learning, Language, literature and Culture Research Method, and Critical Discourse Analysis. Besides, he also had ever become the Secretary of Foreign Language Education department.

Prof. Dr. Jufri, M.Pd is Secretary of Association of Indonesian foreign Language (German) Teacher of South Sulawesi, and Head of Research Institute of State University of Makassar. He is also still active as presenter or participant in various national or international seminars and he has published a number of books entitled Strategy Principle of Language Learning, Language, literature and Culture Research Method, and Critical Discourse Analysis. 


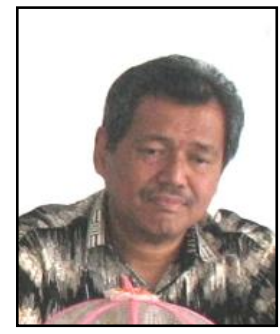

Muhammad Asfah Rahman was born on May 21, 1952 in Selayar, South Sulawesi, Indonesia. Rahman completed his master's and doctorate degrees in the field of Instructional Design and Technology at the University of Pittsburgh, PA, USA in 1986 and 1990 respectively. He completed his undergraduate study in 1979 majoring in the Teaching English as a Foreign Language (TEFL) at the State University of Makassar (formerly Ujung Pandang Institute of Teacher Training and Education), in Makassar, Indonesia.

$\mathrm{He}$ is a LECTURER, and has been teaching English as a foreign language at the State University of Makassar for more than 30 years. Besides, he also has a lot of experience in elementary and secondary school teacher training, teacher professional development, and teaching English to young learners. He was employed for five years as ACADEMIC ADVISOR for USAID Decentralized-basic Education leading university faculty members to develop active learning training packages for elementary school teachers. In the last couple of years, he did a research and a development study whose product is a training package for elementary school teachers of English. At present, his research focuses on module development for improving EFL college writing.

Prof. Rahman is a member of Indonesian Linguistics Society, the Teacher of English as a Foreign Language in Indonesia (TEFLIN), and the Association for Indonesian Educational Technology Profession.

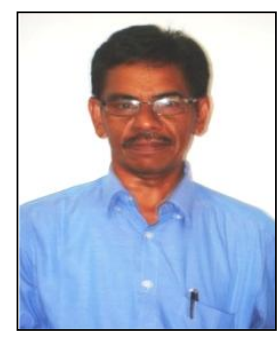

Salam was born in Pare-Pare on June $28^{\text {th }} 1963$. He graduated from elementary school in 1976 and Junior High School in Pare-Pare in 1979, and Senior High School in 1983 in Pare-Pare, and then continuing his study in Third Diplom (D3) Indonesia Language Education and then he took his under graduated study (S1) Indonesian Language and literature department of the Faculty of Letter and Arts of Institute of Teachers Training and Education (IKIP) of Ujung Pandang in 1988. He attended Post Garduated in IKIP Malang (1995). And he back to IKIP Malang to attend Doctoral program in 2004.

In the beginning of March 2001 he was accepted as a Lecturer at the Faculty of Letter and Arts of the Institute of Teachers Training and Education (IKIP) of Ujung Pandang until now. So far, he has published a book entitled Indonesian Language Phonology (Makassar, Makassar State University Publisher, 2004), language Learning Based-Portfolio (Surabaya, Erlangga, 2004), and Reasoning Development in a Paper Working (Makassar State University Publisher, 2007).

Dr. Salam, M.pd is one of the members of Excellent School Development Team Work. He is also one of the National Instructor of 2013 Curriculum. 